\title{
Evidence of Shock Metamorphism Effects in Suevite from the Triffa Plain in North Eastern Morocco
}

\author{
Abdelkader Mokhtari \\ Université Moulay Ismail, Faculté des Sciences, Département de Géologie, BP11201, Beni M’Hamed, Meknès, Morocco \\ *Corresponding Author: mokhtari57@yahoo.fr
}

Copyright $@ 2014$ Horizon Research Publishing All rights reserved

\begin{abstract}
The Triffa plain is located in the north-eastern part of Morocco. It's considered as sedimentary basin of a Quaternary age containing a wide variety of breccias that we consider as impactites. Thereby, we have found monomict breccia and polygenic breccia. The presence of glassy clasts allows us to determine the suevite that contains many indices of shock metamorphism. The effect of the shock is observed in quartz grains that show fractures and planar deformation, the mosaicism texture and ballen-quartz. The pebble breccia shows deformations of shock such as spallation fractures and striation. However, we suggest that the sediments in the Triffa depression are mainly impact breccias.
\end{abstract}

Keywords Impactites, Breccia, Suevite, PFs, PDFs, Spallation, Triffa-plain, Morocco

\section{Introduction}

Erosion, deformation or burial frequently prevent from the recognition of large impact craters on Earth. Recently identified impact structures on the Earth's surface are first marked by a circular or near-circular form, such as a topographic surface or a circular geophysical anomaly [1]. These features may help to detect a new impact crater. The mountain chains surrounding the Triffa plain show no circular structure that may be attributable to the impact crater. Our main aim is to provide an evidence of effect of shock in the Triffa area. We base this study both on the existence of the PDFs deformation in suevite quartz and on the presence of glass as spherule and cinder in this region. In this work we will focus on the breccias in the Triffa plain which are interpreted in literature as a depression filled with the Quaternary sediment deposits. And we report observations and descriptions of the breccias which contain indications of shock that prove that the Triffa basin may have been formed by the shock of meteorite impact.

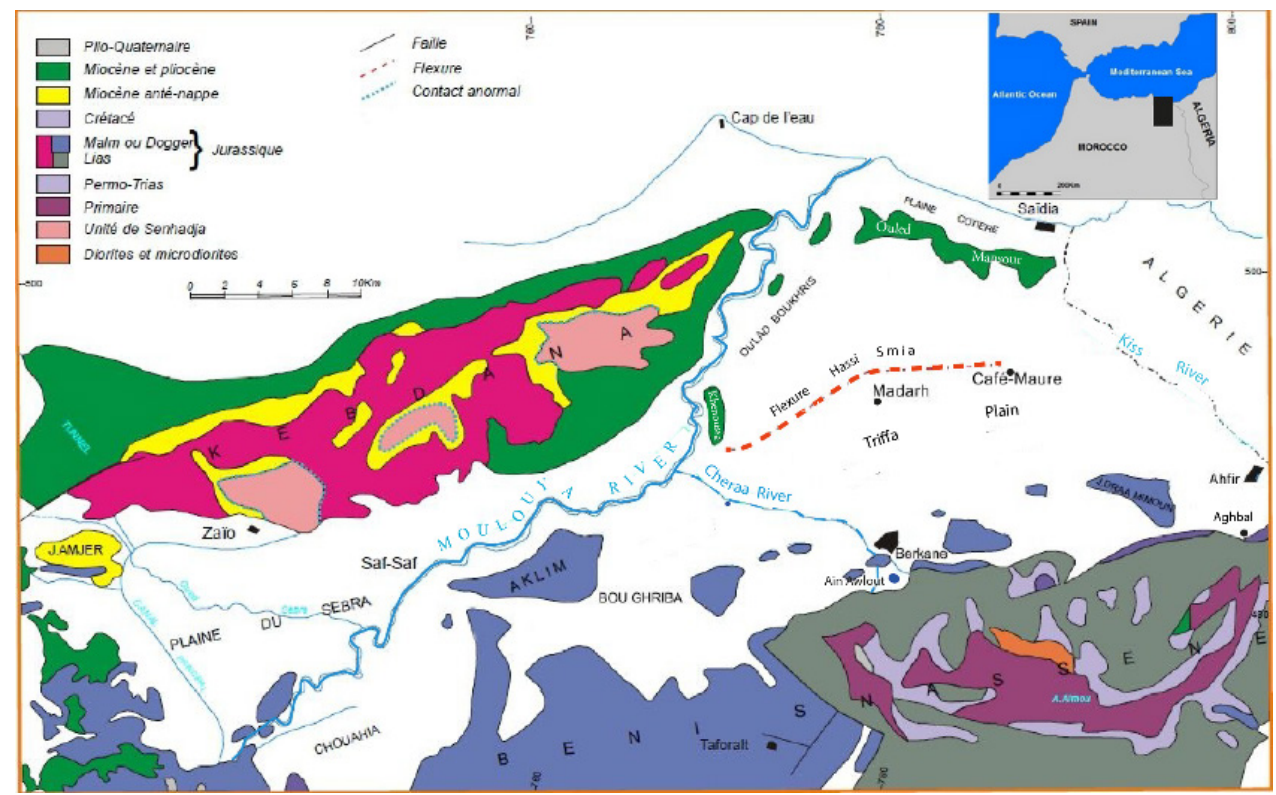

Figure 1. Geological map of the area of the Triffa plain. (Carlier, [2] modified) 


\section{Geologic and Tectonic Overview}

The study area (Triffa Plain), located in the north-eastern part of Morocco, has a surface of about $750 \mathrm{~km} 2$. It is limited by the Ouled Mansour hills in the north, the Beni-Snassen Mountains in the south, the Kiss River in the east and the Kebdana and Moulouya River in the west (Figure 1). The Triffa Plain constitutes a wide synclinal depression formed by the Neogene and Quaternary geological deposits in which the sedimentary sequence overlays a Pliocene marly substratum of Mio-Pliocene age. Red and clayey silt, covers the surface of Triffa basin, which is filled by a series of gravel carbonate levels, sometimes crosscutted by consolidated conglomeratic bars. In the center of the plain, the sediment thickness varies from 50 to $100 \mathrm{~m}$ and decreases brutally at the flexure of ride HassiSmia (Figure 1). This series is based on Neogene conglomerate and marl considered as substrate [3]. The Mesozoic formations crop out to the south within the Beni-Snassen chain. They have a monoclinal structure dipping $25^{\circ}$ to the north. The Lower Jurassic (the Lias) is mainly composed by limestone and dolomite [4].

\section{Breccia}

Breccias constitute a prominent feature of impact structures. Polygenetic breccia and several breccia generations (breccias-within-breccias) are very common $[5,6]$. At present, there is no specific feature in the breccias generated by impact [7]. In the Triffa plain some breccias indicate a deformation like shocked quartz, and spallation. The outcrops in Lake Awlout area and in Cheraa River show different litho logical facies: sandstones, chalky gravel stones, conglomerates and calcareous sandstone with large blocks ( $>2 \mathrm{~m})$. Monomict as well as polygenetic (polymict) breccias are found in this area

\subsection{Monomict Breccia}

The monomict breccias often show an intense mortar texture (Figure 4B) identical to those observed at other impact structures. Many clasts are intensely brecciated, showing angular as well as well-rounded fragments. Intense brecciation of single rocks, comparable to those found in Germany and discussed in detail by Hiuttner1969 [8] for the Ries impact structure, can be observed within the limestone fragments emerging in the ground from the center of Triffa basin.

\subsection{Polymict Breccias}

Large-scale and small-scale polymict breccias (conglomerate) are also present. On the basis of the drilling in the plain, Laaouina [3] notes a wide variation of conglomerate deposits (polymict breccia) covered with red limon (Figure 1). Based on this work, all this conglomerates will be considered as impact products. This breccia can be seen in the outcrops around the lake Awlout, and Cherraa River. These impactites are polymict and they have rounded clasts which are usually of limestone nature. There is a wide range in clast size: from a few millimeters to $>3 \mathrm{~m}$ (Figure 2), the latter ones have been termed megablocks [9]. The Cheraa conglomerate shows a mixed red and white matrix with flow texture. This plastically deformation couldn't be the result of the fluvial deposit (Figure 4E).

\subsection{Suevite}

Suevite is a polymictic clastic matrix breccia containing glass fragments, rock and mineral clasts exhibiting various degrees of shock metamorphism. At the Triffa basin, we observed breccias that match the suevite definition. Only few suevite have been found. This may be the result of erosion, suevite being less resistant to erosion. Two groups are distinguished: a) the first is a compact suevite with clasts of the black quartz (Figure 4C) and are frequently found as scree in the entire Triffa region, or as clasts breccias (Figure $4 \mathrm{~A}$ and $4 \mathrm{~F}), \mathrm{b}$ ) the second suevite group, located in Cheraa River near the road Aklim-Madarh, corresponds to superficial formation overlaying the conglomerate(Figure 3). Like the other suevite types (Ries), the Triffa suevite corresponds to a wide variety of rock fragments, ranging in size from less than a centimeter to about $50 \mathrm{~cm}$. In thin section, the unaltered glass fragments appears as a brown or yellow clasts and take sometimes a droplet shapes, which testifies the aerodynamic effects before the melt solidification. [10,11]. In one sample, the glass shows a fine crystallization of plagioclase (Figure 8B).Quartz fragments and quartz in rock clasts exhibit up to four sets of planar deformation features. The suevite matrix is made of very fine-grained mineral and glass fragments, commonly too fine for light-microscopic identification (Figure 4D).

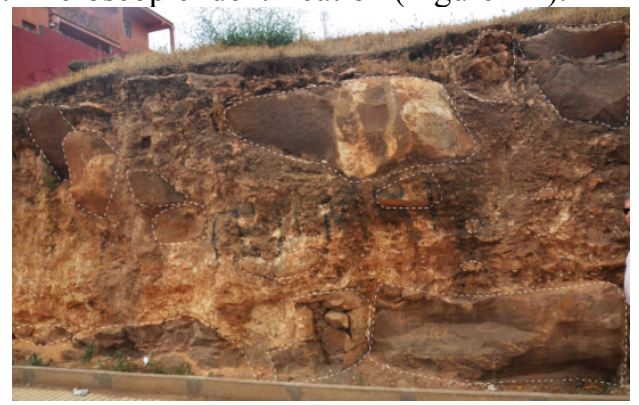

Figure 2. Impact breccias from the Berkane city, containing large blocks $(>2 \mathrm{~m})$

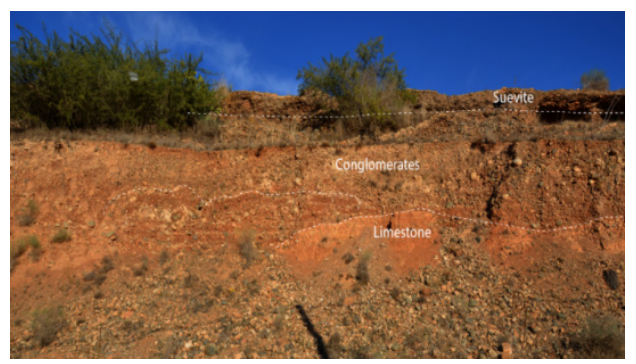

Figure 3. Layering of the suevite on the conglomerate in Cheraa valley 


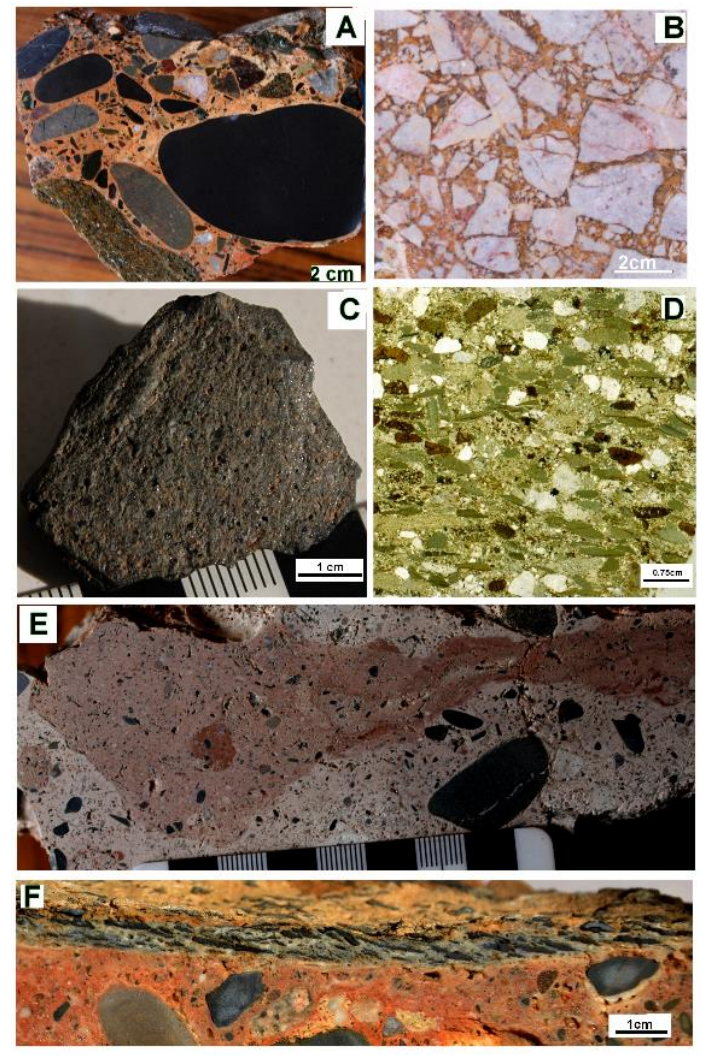

Figure 4. Sawed and polished surface of a breccia with dominant limestone components. (A) Polymict breccia from Awlout with suevite'sclast in lowerleft corner. (B) Monomict breccia with mortar texture. (C) Compact suevite with black clasts of quartz. (D) Note flow texture and plastically deformed component in thin section of Suevite. (E) A flow texture of the pink and white matrix of Cheraa'ssuevite. (F) Slivers of compact suevite in the superficial crust of the pink suevite.

\section{Shocked Quartz}

The quartz grains commonly display some shock-induced micro-deformations, like planar fractures (PFs), planar deformation features (PDFs), grain mosaicism and more rarely ballen texture (Figure 6).

\subsection{PDFs}

It is generally accepted that shock metamorphism in rocks must be considered as a proof of meteorite impact [12]. According to their intensity, shock waves leave different traces in a mineral. Planar deformation features (PDFs) belong to the most important ones such as the case shown in quartz. These peculiar structures are closely spaced parallel (5 to $10 \mu \mathrm{m}$ ), optically lamellae following crystallographic planes in the quartz grains. According to current knowledge [13], multiple sets of these closely spaced isotropic lamellae can only originate from extreme shock pressures. Planar features, identical in form to those described from other impact sites were recognized in quartz-bearing suevite collected from Triffa plain (Figure 5). The PDFs are generally decorated with tiny fluid inclusions which greatly facilitate their detection under the microscope. The decorations have resulted from post-shock annealing and aqueous alteration of non-decorated PDFs [14]. Both decorated and non-decorated PDFs have been found in the Triffa quartz.
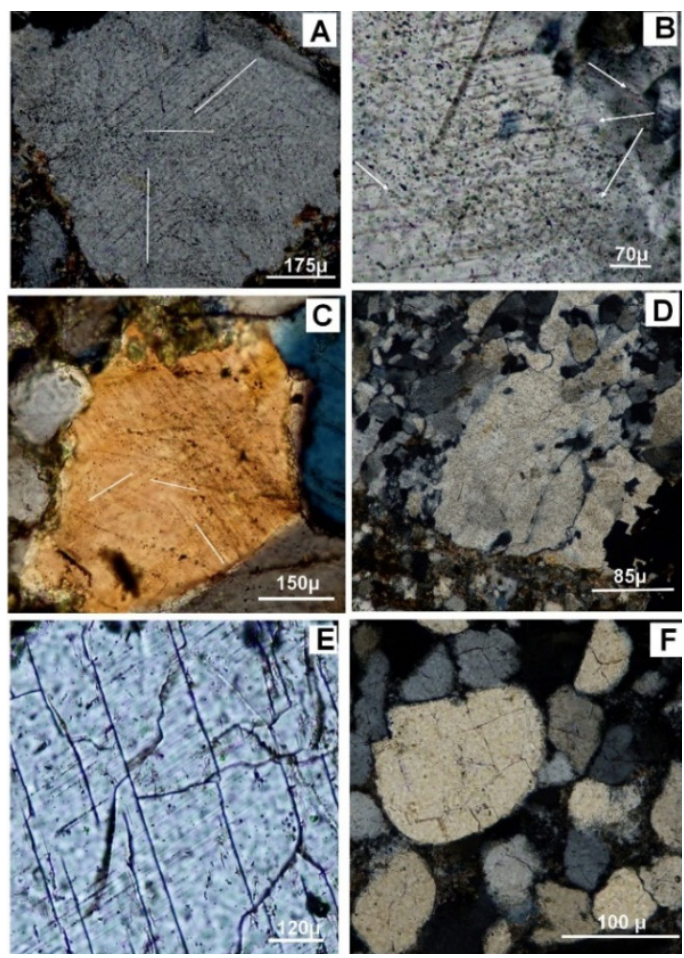

Figure 5. Microphotographs of thin sections showing typical deformation patterns in clasts of suevite resulting from shock metamorphism. All images were taken with crossed nicols(A,B,C) Shock metamorphism effect in quartz grains exhibiting several sets of partly decorated with tiny fluid inclusions.(D) Mosaicism habit of quartz, (E) PDFs and PFs in plagioclase of Cheraasuevite(F) Fractured quartz in sandstone clast. All suevites are from Lake Awlout except E

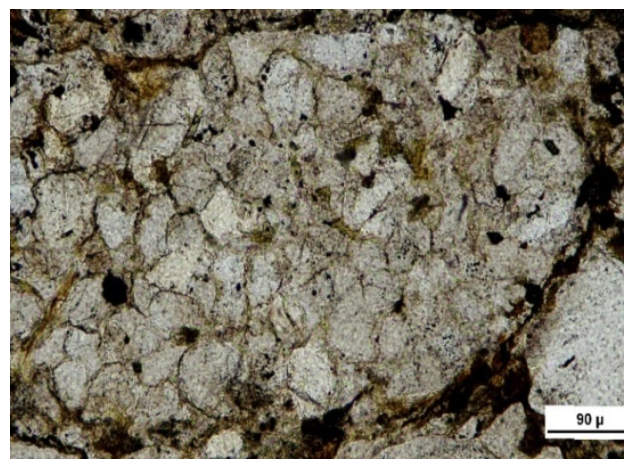

Figure 6. Microphotographs of ballen quartz in suevite from Awlout

Planar fractures $(\mathrm{PFs})$ in quartz grains occur as thin open fissures generally spaced greater than $20 \mu \mathrm{m}$. They were observed in quartz and feldspar (Figures 5E and 5F).

\subsection{Mosaicism}

Under the microscope, shock-inducted mosaicism appears as a highly irregular mottled extinction pattern in quartz with 
or without planar microstructures. This mosaicism is commonly observed in different quartz grains with PDFs in the Triffa suevites (Figure 5D) and in the conglomerate matrix from Aghbal. Mosaicism is recognized by a mottled extinction pattern. Unlike undulatory extinction (observed in tectonically deformed quartz), mosaic extinction does not sweep through a grain but occurs at discrete positions as the microscope stage is rotated [15].

\subsection{Ballen-Bearing Quartz}

Ballen-bearing quartz was identified in fragments of suevite from Awlout area. The outlines of the ballen loops are usually oval or rounded shaped.

\section{Spallation}

The shocked cobbles from the Miocene conglomerates in Aghbal outcrops have surfaces marked by Mini-Craters (1 to $5 \mathrm{~cm}$ of diameter) and are deeply fractured. The widely open fractures in the coherent cobbles with a smooth surface couldn't be of tectonic origin [16].

These so called spallation features are the typical result of dynamic shock deformation well known from observed conglomerates near large impact structures $[17,18]$.

Other impact deformations are observed in heavily striated and polished cobbles found in the Triffa plain (Figure 7). Striated and polished clasts are well-known from other impact places like the Ries impact structure [19], the Azuara-Rubielos.

\section{Glass}

Cinder rocks constitute the impactites on the field around the Lake Awlout and they reflect a volatile-rich melt (Figure 9).

The glassy spherules are solidified from melt or condensed from vapor. Larger $(>1 \mathrm{~cm})$ melt droplets cool rapidly and form rocks composed entirely of glass, called tektites [20]. The spherules are generally $<1 \mathrm{~mm}$ across and are called either microtektites (if they consist of glass without primary microlites) or microkrystites (if they contain primary microlites [21]. Most microtektites are spherical, but rotational forms such as teardrops, also exist (Figure 8). The rotational shapes are produced by rapid rotation of the droplets while still molten.

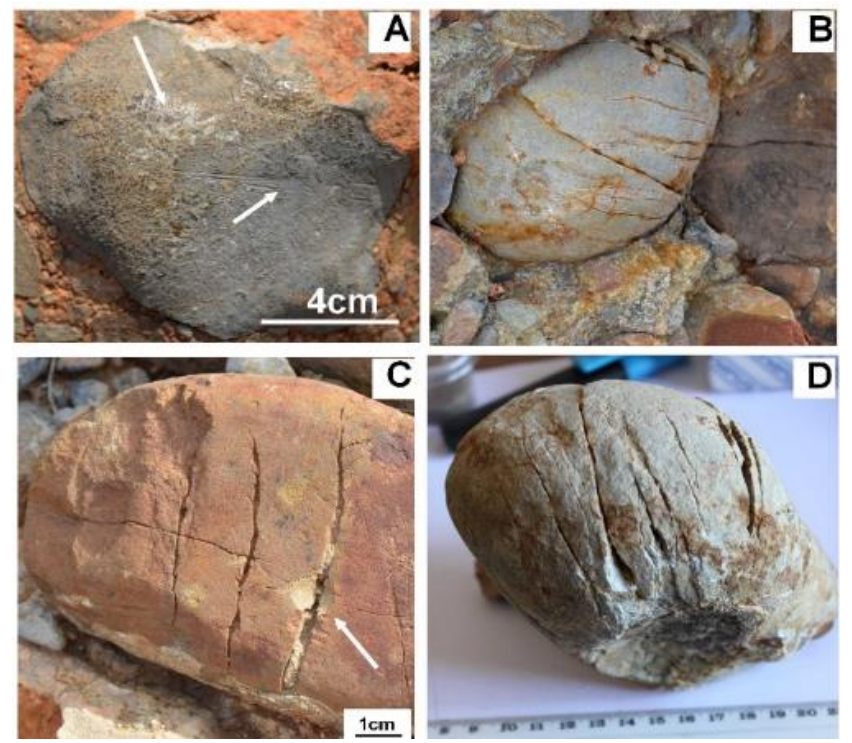

Figure 7. Striation and mirror polish on limestone clast from Lake Awlout. (B,C,D) Strongly deformed cobbles in Miocene outcrop (Aghbal) showing subparallel fracturing and cratering.
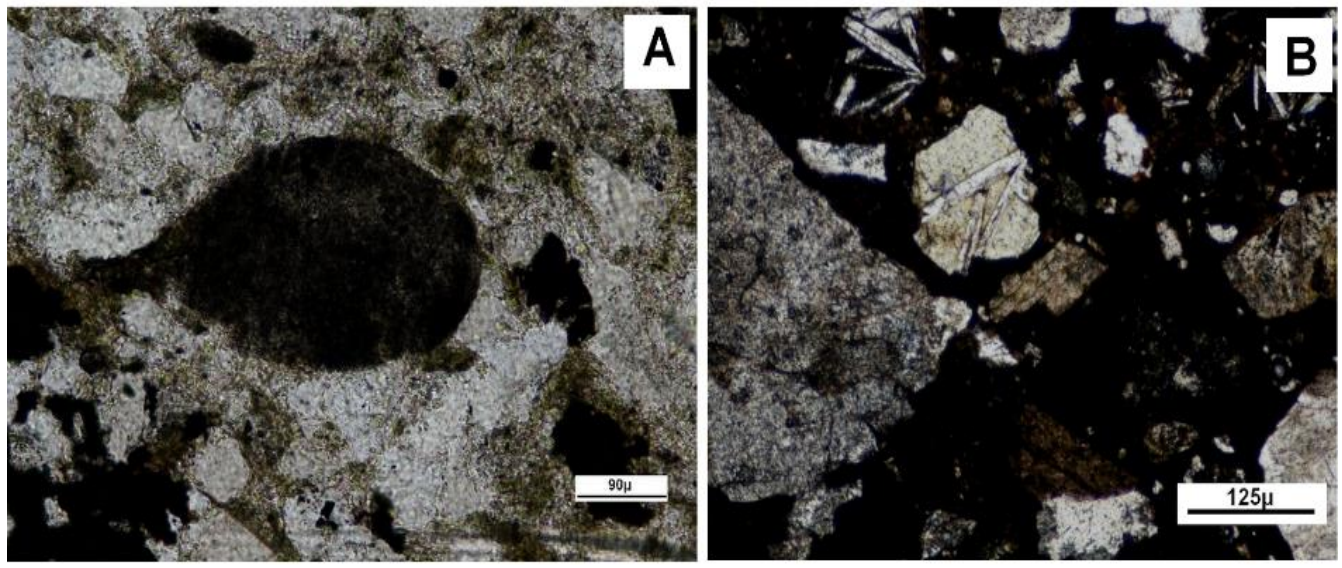

Figure 8. Micro-photomicrograph of droplet melt in thin section of suevite, (B)plagioclase crystallization in yellow glass of the suevite 


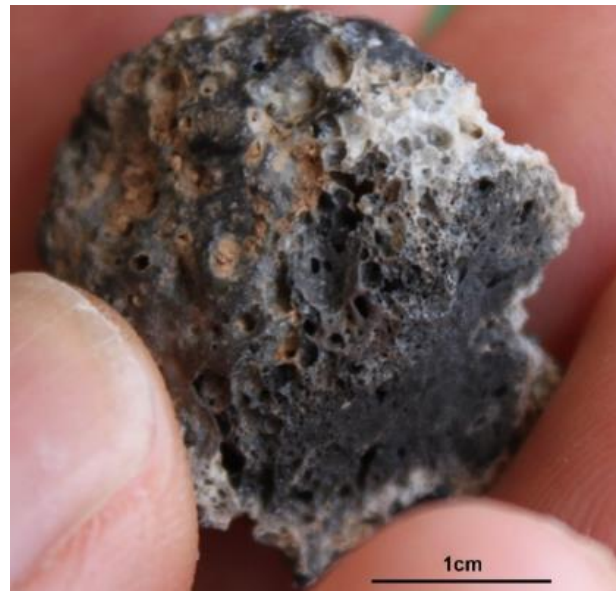

Figure 9. Lava flow features cinder rock with elongated vacuoles (lower part of the sample) indicates the flow melt

\section{Conclusions and Discussions}

Based on petrographic characterization, two distinct breccia types were identified in the breccia deposits: bunt breccia and suevite. The breccia contains angular clasts of older sedimentary material and of granitic to metamorphic basement rocks. A large variety of micro-deformation features was found in individual mineral clasts: mosaicism structure, ballen-quartz; planar fractures (PFs) and planar deformation features (PDFs) are commonly found in quartz.

The presence of planar micro-deformation features in the suevite of the Triffa plain is an evidence that these rocks was formed as a result of asteroid or comet impact. The shock deformation features in components of the breccias encountered in this region and the presence of glass(spherical or cinder) strongly also suggest that the breccias were formed by impact processes.

The fractured cobble and the shocked quartz in Miocene conglomerate allow us to propose that the impact occurred in the early Miocene and this conglomerate is an impactite breccia. Though no meteoritic fragments has been found so far in these areas, the origin is proven by the evidence of impacts on magmatic and sedimentary rocks and the existence of aerodynamic ejecta.

The Triffa fields deserve further detailed studies and discussion on its origin. These objectives will be accomplished in forthcoming field work investigations.

\section{Acknowledgements}

The author thanks Ali Moukadiri for reading an earlier version of the manuscript and Abdelkader El Maz for discussion.

\section{REFERENCES}

[1] A. L. Cortes. Cosmic impact versus terrestrial origin of the Azuara structure (Spain), A review Meteoritics\& Planetary Science Vol.37, 875-894, 2002.

[2] P. Carlier. La plaine des Triffa. In : Ressources en eau du Maroc : 1. domaines du Rif et du Maroc oriental. Notes \&Mém. Serv. Géol. Maroc, Vol. 231, 301-315, 1971.

[3] A. Laaouina. Le Maroc nord-oriental: relief, modelé et dynamique du calcaire. Publication du Rectorat de l’Univ.Mohammed I, Oujda, Maroc, 605 pages, 1990.

[4] T. Naciri. Evolutions sédimentaires, environnements et contrôles dans le Lias-Dogger des Béni Snassen Orientaux (Maroc oriental). Doctorat ès-Siences,Mohamed I Univ., Fac. Sci. Oujda, 243 pages, 1994.

[5] F. Hörz, H. Gall, R. Hûttner, V.R. Oberbeck. Shallow drilling in the Bunte Breccia impact deposit, Ries Crater, Germany, in: Impact and Explosion Cratering, D.J. Roddy, R.O. Pepin, R.B. Merrill, 425-448, Pergamon, Press, New York, N.Y., 1977.

[6] F. Hörz, R. Ostertag, D. A. Rainey.Bunte breccia of the Ries: continuous deposits of large impact craters, Rev. Geophys. Space Phys. Vol.21, 1667-1725, 1983.

[7] K. Ernstson, W. Hammann, J. Fiebag, G. Graup. Evidence of an impact origin for the Azuara structure (Spain), Earth Planet. Sci. Lett. Vol.74, 361-370, 1985.

[8] R. Hüttner.Bunte Trümmermassen und Suevit, in: Das Ries-Geologie, Geophysik, und Geneseeines Kraters, Bayer. Geol. Landesamt, ed., Geol. BavaricaVol.61, 142-200, 1969.

[9] J. Pohl, D. Stöffler, H. Gall, and K. Ernstson. The Ries impact crater. In Impact and explosion cratering, edited by Roddy D. J., Pepin R. O., and Merrill R. B. New York: Pergamon Press, 343-404.1977.

[10] W. V. Engelhardt, G, Graup.Suevite of the Ries crater, Germany: source rocks and implications for cratering mechanics, Geol. Rundsch, Vol.73, 447-481, 1984.

[11] W. V. Engelhardt. Distribution, petrography and shock metamorphism of the ejecta of the Ries crater in Germany a review, TectonophysicsVol.171, 259-273, 1990.

[12] BM. French. Traces of Catastrophe: A Handbook of Shock-Metamorphic Effects in Terrestrial Meteorite Impact Structures. Lunar and Planetary Institute, Contribution no. 954, Lunar and Planetary Institute, Houston, Texas, USA. 120 pages, 1968.

[13] D. Stöeffler, F. Langenhorst. Shock metamorphism of quartz in nature and experiment: I. Basic observations and theory. Meteoritics\& Planetary Science, Vol.29, 155-181, 1994.

[14] O. Goltrant, H. Leroux, J. C. Doukhan, P. Cordier. Formation mechanisms of planar deformation features in naturally shocked quartz. Physics of the Earth and Planetary Interiors, Vol.74, 219-240, 1992.

[15] V.F. Velázquez, C. Riccomini, J. M. A. Sobrinho, M. A. J. S. Pletsch, A. E. M. Sallun, W. S. Filho, J. Hachiro. International Journal of Geosciences, 4, 274-282 2013. http://dx.doi.org/10.4236/ijg.2013.41A025 Published Online January 2013 (http://www.scirp.org/journal/ijg)

[16] K. Ernstson, W. Mayerb, A. Neumairb, B. Rappenglückb, M. 
A. Rappenglückb, D. Sudhausc, K. W. Zellerd. The Chiemgau Crater Strewn Field: Evidence of a Holocene Large Impact Event in Southeast Bavaria, Germany Journal of Siberian Federal University. Engineering \& Technologies Vol. No1, 72-103, 2010.

[17] K. Ernstson, M. R. Rampino, M. Hiltl. Cratered of cobbles in Triassic Buntsandstein conglomerates in NE Spain: Shock deformation of in-situ deposits in the vicinity of large impacts, Geology, Vol.1, 11-14, 2001.

[18] K. Ernstson, F. Claudin, U. Schüssler, K. Hradil. The mid-Tertiary Azuara and Rubielos de la Cérida paired impact structures (Spain), Treballs del Museu de Geologia de Barcelona, Vol.11, 5-65, 2002.

[19] E. C. T. Chao. Mineral produced high pressure striae and clay polish: Key evidence for nonballistic transport of ejecta from Ries crater, Science, Vol.194, 615-618, 1997.

[20] C. Koeberl, P. Claeys, L. Hecht, I. McDonald, Geochemistry of impactites, Elements Vol.8, 37-42, 2012.

[21] BP. Glass, CA.Burns.Microkrystites:a new term for impact-produced glassy spherules containing primary crystallites, Proceedings of the 18th, Lunar and Planetary Science Conference, $455-458,1988$. 